\title{
Research on the Integration of Innovation and Entrepreneurship Education and Specialty Education in Higher Vocational Engineering
}

\author{
Zhu Yu ${ }^{\mathrm{a}}$, Guan Wei \\ Dalian Vocational \& Technical College, Liaoning, Dalian \\ azy-dlvtc@163.com, b992129276@qq.com
}

Keywords: Innovation; Entrepreneurship; professional education; idea; quality

\begin{abstract}
At present, higher education in our country mainly focuses on professional education. Colleges and universities carry out professional education according to the set curriculum system according to the training plan of professional talents. Therefore, if we want to integrate innovative entrepreneurship education with professional education in a reasonable way, it is definitely not just a matter of adding a few innovative entrepreneurship courses. Instead, the concept of innovative entrepreneurship education should be incorporated in every aspect of the professional training program and curriculum system. However, at present, most colleges and universities in our country do not have a comprehensive understanding of innovative entrepreneurship education, and do not integrate the education of innovative and entrepreneurial talents into the talent training system of professional education, it is not closely that the combination of innovative entrepreneurship education and professional education. The independent establishment of innovative entrepreneurship education curriculum and professional learning of the relationship is not even independent, leading to the separation of innovative entrepreneurship education and professional education, students absorb innovative entrepreneurial knowledge and professional knowledge independent in the mind. In practice, innovative entrepreneurship education in colleges and universities is difficult to meet the needs of market and society. Aiming at the problems existing in professional education and innovative entrepreneurship education, this paper probes into the organic integration of innovative entrepreneurship education and professional education.
\end{abstract}

\section{Background}

"Opinions on Vigorously Promoting Innovation and Entrepreneurship Education in Colleges and Universities" interpretation of innovative Entrepreneurship Education: innovative Entrepreneurship Education is to meet the needs of economic, social and national development strategies. And a teaching concept and model.

Innovation and entrepreneurship education is essentially an educational activity to cultivate students' innovative spirit, entrepreneurial quality and entrepreneurial skills, that is, to train students how to adapt to social survival, to choose their own jobs, and to seek employment by themselves.[2]

The concept of innovative entrepreneurship education can be expressed as follows: innovative entrepreneurship education is to cultivate students' innovative entrepreneurial spirit, to shape students' innovative entrepreneurial personality, to improve students' comprehensive quality of innovation and entrepreneurship. Educational activities to improve students' innovative and entrepreneurial ability as the basic value orientation. The core connotation of innovative entrepreneurship education is to change the traditional educational thought, to renew the backward educational idea as the forerunner, to combine the innovative entrepreneurship education with the specialized education, and to face all the students in colleges and universities. The integration of the whole process of talent training as the basic principle, in order to shape the students' innovative and entrepreneurial personality, improve the students' comprehensive quality of innovation and entrepreneurship, improve the students' creativity. The core of the new entrepreneurial ability is the reform and the training mode of innovative talents, and the quality of the training of innovative entrepreneurial talents is constantly improved [3]. 


\section{The Present Situation of Engineering Specialty Education in Higher Vocational Education}

\subsection{Substantive Cooperation between Schools and Enterprises is not Close Enough.}

At present, the service as the purpose, the employment as the guidance specialized education system can be embodied in the various professional occupation posts and the occupation kind, also promoted the higher vocational education and the innovation enterprise education close union.

The essence of higher vocational education is the cooperation between schools and enterprises, and it is also the objective requirement of our own development. Our current cooperation between schools and enterprises is in the exploratory stage, the cooperation with enterprises is not close enough, and schools can provide too few services for enterprises. There are too few policies and regulations to promote the deep integration of schools and enterprises. Most of the time students still do theoretical study in school. The time of enterprise practice and the content of practice are limited, which can not fundamentally solve the problem of learning students' job skills. Another is the employment of students, engaged in first-line labor, income is relatively low, lack of attraction.

\subsection{The Construction of Teachers is Lagging Behind, and the Definition of Double-Professionally-Titled Teachers is not Clear.}

The development of education, especially the development of higher vocational education, is closely related to the ability of teachers. Teachers' vocational education concept is weak, teaching is mainly based on traditional teaching form, which is contrary to the original intention of vocational education. In the field of higher vocational education, there is no clear definition of "double qualified" teacher quality, and there are different standards for the concept of "double-professionally-titled" in each region and school. At the same time, there are also problems, most of the teachers of vocational colleges come out of the school directly into the school teaching, have not engaged in relevant career practice, thus showing and high. There is a gap between the requirements of vocational education and teachers' professional ability. In addition, our higher vocational education teacher training system is not perfect, regional training base is missing.

\subsection{Inadequate Training Conditions in Schools.}

The establishment of practical training positions in schools is not perfect, and the actual production environment in most schools is quite different from that in factories, so it is naturally impossible to complete the actual design of production positions. The training equipment is short of practical training equipment and is different from the actual position and skill greatly. Due to the influence of the site and the amount of funds, the training equipment can not be updated in time, and the old equipment problem appears obviously. Under the influence of the actual situation of personnel arrangement in various schools, the phenomenon of insufficient number of trained teachers is common. Therefore, the content arrangement of practical training is sometimes not compact enough to take into account many factors of safety, so it is not possible to provide detailed guidance.

\section{Current Situation of Innovation and Entrepreneurship Education for Engineering Students in Higher Vocational Education}

In recent years, the government has issued a series of guiding documents for the development of innovative entrepreneurship education in colleges and universities, which provides policy support for the cultivation of students' innovative entrepreneurial ability and quality. Higher vocational education institutions actively promote educational and teaching reform, increase the strength of innovative entrepreneurship education for college students, build innovative entrepreneurial practice platforms and carriers of innovative entrepreneurial activities, and create a better atmosphere for innovative entrepreneurship. Creating a good environment for innovation and entrepreneurship, and improving the innovative spirit, entrepreneurial awareness and innovative entrepreneurial ability of engineering students in higher vocational education, "to improve the quality of higher education, to promote the all-round development of students, and to promote the employment of graduates," 
Service country Modernization has played an important role [4].

Some prominent problems in the process of Innovation and Entrepreneurship Education in higher Vocational Education institutions:

\subsection{Lack of Integration of Innovation and Entrepreneurship Education and Professional Education.}

At present, many colleges and universities of higher vocational education regard innovative entrepreneurship education as quality-oriented education, and pay less attention to innovative entrepreneurship education, which cannot be closely combined with professional education.

\subsection{The Strength of Teachers is Relatively Weak.}

At present, most of the teachers who guide students' innovative entrepreneurship education are counselors. Few of them have professional background and few have experience of innovative entrepreneurship. Most of the knowledge comes from theory, which matches the original intention of innovative entrepreneurship education. To some extent, it restricts the effective implementation of innovative entrepreneurship education in higher vocational education institutions.

\subsection{Lack of Platform and Imperfect Supporting Mechanism.}

Innovation and entrepreneurship education is lack of practical platform, the depth of integration of industry and education is not enough, the platform construction of scientific and educational cooperation needs to be further promoted, the supporting system and mechanism are not perfect, the evaluation system is not perfect. The development of innovative and entrepreneurial education for engineering students in higher vocational education has been restricted to a certain extent.

\section{A Probe into the Organic Integration of Engineering Specialty Education and Innovative Entrepreneurship Education in Higher Vocational Education}

\subsection{It is Imperative to Strengthen the Cooperation between School and Enterprise.}

Deep integration of schools and enterprises, building a platform for the integration of engineering and learning, science and education collaborative education platform, scientific and technological innovation, achievements transformation platform, the school and enterprises fully play their own characteristics, part-time. That is, school teachers participate in the development of applied technology, solve practical problems in practical production, innovate in the continuous improvement of production, and improve teachers' personal practical ability when they come into contact with advanced technology in enterprises. Therefore, as the basis of guiding students' study, enterprise personnel participate in the work of talent training in schools, and provide strong support for the professional construction, practical training base construction, teachers' construction and so on. Regular meeting Joint meeting of schools and enterprises to solve problems encountered by personnel in practical work.

To establish a cooperative platform with enterprises and entrepreneurial innovation parks, which will serve as a practical platform for innovative entrepreneurship education, and guide and help through the technical personnel and related personnel of the enterprises, as well as the start-up parks for college students, incubators and small and micro enterprises. Serving students to develop innovative activities and entrepreneurial practices.

\subsection{Effective Construction of Teaching Staff.}

If we want to construct teachers reasonably and effectively, we should change teachers' vocational education idea, change the traditional teaching mode, and combine the stylized teaching with the demand of vocational skill posts. The advanced scientific and technical knowledge of this major is transmitted to the students in time, and the students are trained in professional accomplishment, entrepreneurial innovation concept and professional skills. To carry out general education on innovation and entrepreneurship, to inspire students' innovative thinking, to guide students to participate in the practice of innovative entrepreneurship, to strengthen the training of 
existing teachers, and to strengthen the innovative thinking of teachers. Integrating the idea of Innovation and Entrepreneurship into Teachers' Conception of Vocational Education In order to enable teachers to integrate innovative entrepreneurship education with the knowledge theory education of students, the whole vocational education can always be integrated.

To establish communication and cooperation mechanisms among successful entrepreneurs in the same industry and enterprises, to enhance the teaching staff's innovative entrepreneurial practice education and guidance ability, to hire the industry, to hire successful entrepreneurs to teach in schools and to instruct students to carry out innovative entrepreneurial activities, To strengthen the practicality and effectiveness of innovative entrepreneurship education, to set up innovative entrepreneurship education teaching team, to promote the interaction between teachers, and to improve the quality and level of innovative entrepreneurship education.

\subsection{Perfect the School Training Conditions and Projects, and Build an Innovation and Entrepreneurship Platform.}

Practical training in school is the premise and foundation of students' understanding of professional skill knowledge, and the design of good practical training project is the key to enhance students' professional skill knowledge. It is necessary to strengthen the development and implementation of the project of productive training in the school, combine the professional ability of the post group with the project of practical training in the school effectively, and run through the project of practical training and the post quality education throughout the professional skill education. Pay attention to the organic combination of teaching and practice, the interactive fusion of theory and practice, increase the proportion of practical links of innovative entrepreneurship curriculum, carry out diversified practical teaching activities, guide students to experience, participate in innovative entrepreneurial practice activities; Strengthening higher vocational education The orientation of Innovation and Entrepreneurship in graduation Design of Engineering students.

Set up an innovative entrepreneurial platform in school, and effectively carry out the guidance education and practice of students' innovation and entrepreneurship. To strengthen the construction of professional laboratories, virtual simulation laboratories, entrepreneurship laboratories, and so on, to open up scientific and technological innovation resources, and to promote the integration of professional education and innovative entrepreneurship education, Provide experimental teaching platform for engineering students of higher vocational education to carry out innovative entrepreneurial practice.

\section{Acknowledgement}

Researching results of 2017 subject "Research on the Integration of Innovation and Entrepreneurship Education and Specialty Education in Higher Vocational Engineering” of the 13th Five-Year Plan of Liaoning Province Education Science (Project Number: JG17EB061, Topic Moderator: Guan Wei).

\section{References}

[1] Views of the General Office of the State Council on the implementation of the Reform of Innovation and Entrepreneurship Education in Colleges and Universities. EB $\backslash \mathrm{OL}$, http://www.moe.edu.cn/publicfiles/business/htmlfiles/moe/moe_1778/201505/187212.html

[2] Tang Jiafang. Innovative Entrepreneurship Education and the Sustainable Development of College students themselves. Education and occupation. 2008(10):18-19.

[3] Ouyang Hongjie. Research on the practical Teaching system of Colleges and Universities oriented to the cultivation of innovative Entrepreneurship ability. Huazhong Normal University. 2014

[4] General Office of the State Council and General Office of the State Council on the 
implementation of the reform of innovative entrepreneurship education in institutions of higher learning (Issued by the State Office (2015) No.36). http://www.gov.cn/zhengce/content/2015-05/13/content_9740.htm.

[5] Wu Aihua, Hong Yongfeng, Yang Qiubo. Speed up the Development and Construction of New Engineering courses and actively adapt and lead the new economy. Research on higher Engineering Education. 2017(1):3-7.

[6] Shao Yuehua. A study on the effective Integration of innovative Entrepreneurship Education and Professional Education in higher Vocational Colleges. Vocational and technical education in China.2016 (10):76-79. 